\title{
First detection of Trypanosoma vivax in cattle in the state of Bahia, Brazil, based on parasitological and molecular analyses
}

\section{Primeira detecção de Trypanosoma vivax em bovinos no estado da Bahia, Brasil baseada em análises parasitológica e molecular}

Hayala Caroline Silva Ferreira Gomes'; Igor Leonardo de Jesus Genipapeiro2; Fabíola Teixeira Andrade ${ }^{2}$; Danielle de Campos Vieira Barbosa ${ }^{2}$; Leonardo Ribas Pacheco2; Regiane Pereira Benevides Silva2; Epaminondas do Patrocínio ${ }^{3}$; Cristiane de Jesus Barbosa4; Jorge Raimundo Lins Ribas; Luciana Veiga Barbosa6*

\section{Highlights}

This paper reports the first detection of trypanosomiasis in cattle in Bahia, Brazil.

Blood smear analysis is an alternative method for the diagnosis of trypanosomiasis.

The results confirm the higher sensitivity of PCR for trypanosomiasis.

\section{Abstract}

We report the first detection of Trypanosoma vivax in Bahia state based on blood smear and PCR analyses. A total of 623 bovine blood samples were collected over two years. Parasitological analysis by smear technique detected the presence of T. vivax in $0.3 \%$, while molecular analysis by PCR showed a prevalence in $18.9 \%$ of the samples. This study demonstrated the higher sensitivity of molecular analysis in the diagnosis of hemoparasitosis caused by T. vivax in dairy cattle herds.

Key words: Trypanosomiasis. Blood smears. PCR. Northeast of Brazil.

1 Master's Student in Genetics and Animal Breeding at State University Paulista "Júlio de Mesquita Filho", UNESP, Jaboticabal, SP, Brazil. E-mail: hayala_caroline@hotmail.com

2 Graduate Students in Veterinary, School of Veterinary Medicine and Zootechnics, Federal University of Bahia, UFBA, Salvador, BA, Brazil. E-mail: igorljgenipapeiro@gmail.com; fabi.andrade@live.com; daniellevieira_93@live.com; leorp2206@gmail.com; regiane_benevides@hotmail.com

${ }^{3}$ Chemistry Technician, Brazilian Agricultural Research Corporation, EMBRAPA, Cruz das Almas, BA, Brazil. E-mail: epaminondaspatrocinio@gmail.com

${ }^{4}$ Researcher, Brazilian Agricultural Research Corporation, EMBRAPA, Cruz das Almas, BA, Brazil. E-mail: cristiane. barbosa@embrapa.br

5 Veterinarian, Bahia Agricultural Defense Agency, ADAB, Salvador, BA, Brazil. E-mail: jrlribas@gmail.com Prof $^{\mathrm{a}} \mathrm{Dr}^{\mathrm{a}}$, Institute of Biology, Federal University of Bahia, UFBA, Salvador, BA, Brazil. E-mail: veiga@ufba.br

* Author for correspondence

Received: July 04, 2020 - Approved: Feb. 24, 2021 


\section{Resumo}

Relatamos a primeira detecção de T. vivax no estado da Bahia baseada em esfregaços sanguíneos e PCR. Foram coletadas 623 amostras de sangue de bovinos ao longo de dois anos. An análise dos esfregaços detectou a presença do T. vivax em 0,3\% delas, enquanto a detecção molecular por PCR mostrou uma prevalência em 18,9\%. Este estudo evidenciou a maior sensibilidade da análise molecular no diagnóstico da hemoparasitose causada pelo T. vivax, em rebanhos bovinos leiteiros.

Palavras-chave: Tripanossomíases. Esfregaço sanguíneo. PCR. Nordeste do Brasil.

Trypanosoma vivax is the hemoparasite responsible for causing trypanosomiasis in ruminants. This disease presents a clinical and subclinical form and has a negative economic impact, leading to decreased meat and milk production, decreased fertility rates, miscarriage, and even death of the animal (Grisi et al., 2014). In the Americas, transmission occurs through hematophagous insect species of the genus Stomoxys and Tabanus and the reuse of contaminated syringes (Bastos et al., 2017). The most commonly used technique for the diagnosis of the disease is parasitological analysis using blood smear (Madruga, 2004), but the most sensitive is molecular analysis such as polymerase chain reaction (PCR) (Cortez et al., 2009).

In 2016, some owners of cattle herds in the southern region of Bahia notified the official animal health service of the state that some animals showed clinical signs similar to those in trypanosomiasis. In a previous clinical examination, these animals were found to be anemic and had a low body condition score. Based on these notifications, this study aimed to analyze the blood of the animals from these herds to confirm the presence of T. vivax in cattle in the region using blood smear and PCR analysis.

Between May 2016 and May 2018, 623 blood samples were collected from animals belonging to cattle herds of three counties in the southern region of the state of Bahia. These included samples from 105 cows from Ibirataia (14 4' 10" S, 39³8' 26" W, 149 m altitude, predominantly tropical climate with an average annual temperature of $23.6^{\circ} \mathrm{C}$ and annual precipitation of $1269 \mathrm{~mm}), 434$ cows from Prado (170 20' 28" S, $39^{\circ} 13^{\prime} 15^{\prime \prime}$ W, 4 m altitude, predominantly tropical climate with an average annual temperature of $24.6^{\circ} \mathrm{C}$ and annual precipitation of $979 \mathrm{~mm})$, and 84 cows from Jucuruçu (16 49' 47" S, 40 9' 54" W, $365 \mathrm{~m}$ altitude, predominantly tropical climate with an average annual temperature of 24.6 ${ }^{\circ} \mathrm{C}$ and annual precipitation of $1147 \mathrm{~mm}$ ). All of the 623 samples collected were analyzed. The animals belonged to different breeds (Swivel, Holstein, Nellore, and Crossbred) raised in a semi-intensive regime and ranged from 2 months to 16 years of age. Some animals were asymptomatic, while others presented clinical signs such as apathy, fever, anorexia, weakness, pale mucous membranes, progressive edema, decreased milk production, stillbirths, and increased superficial lymph nodes.

Blood samples were collected by puncturing the sacrococcygeal vein according to the Vacutainer $^{\circledR}$ system with EDTA potassium-BD, and subsequent smears were prepared. The blood smears were stained by the panoptic method and dried at room 
temperature with three repetitions per sample. The slides were analyzed using a Bioval ${ }^{\circledR}$ optical microscope under the 100X objective lens.

Molecular analysis was performed according to the method described by Araújo et al. (2009). The extracted DNA was quantified usinganL-Quant ${ }^{\circledR}$ spectrophotometer $(260 / 280$ $\mathrm{nm})$, then subjected to electrophoresis in a $1.0 \%$ agarose gel and stained with ethidium bromide for visualization under ultraviolet (UV) light. The samples were stored in a freezer at $-20^{\circ} \mathrm{C}$.

PCR analysis was performed using two pairs of primers. The first pair of primer was specific to the ribosomal subunit 18SrRNA (GenBank access U22316), 18STnF2 (5'CAACGATGACACCCATGAATTGGGGA3') and 18STnR3 (5'TGCGCGACCAATAATTGCAATAC3'), with amplification products of 710 bp (Madruga, Araújo, Lima, \& Pádua, 2006). The second pair of primer was specific to repeated DNA sequences encoding cysteine proteases (cathepsin L), DT0155 AAGCTTCCACGAGTTCTTGATGATCCAGTA3') and TviCatL1 (5'GCCATCGCCAAGTACCTCGCCGA3'), with amplification products of $177 \mathrm{bp}$ (Cortez et al., 2009). The reactions were carried out as described by Madruga et al. (2006), with ultrapure water as the negative control and the DNA samples from the blood of infected cattle. The amplification process consisted of an initial denaturation step at $94^{\circ} \mathrm{C}$ for 2 minutes, followed by 30 cycles of denaturation at $92^{\circ} \mathrm{C}$ for 60 seconds, annealing at $57^{\circ} \mathrm{C}$ for 60 seconds, elongation at $72{ }^{\circ} \mathrm{C}$ for 60 seconds, and finally, an extension step at $72{ }^{\circ} \mathrm{C}$ for 5 minutes. The reactions were carried out in a Veriti 96 Thermal Cycler $^{\circledR}$. The PCR products were visualized by electrophoresing in a $2 \%$ agarose gel in TBE buffer at $100 \mathrm{~V}$ in the presence of a $100 \mathrm{bp}$ ladder marker. The gels were photographed using the LPIXEL Image $\mathrm{HE}^{\circledR}$ system.

The results are shown in Figure 1 and Table 1. Blood smear analysis revealed the presence of flagellated protozoa with a subterminal kinetoplast, narrow undulating membrane, and medial nucleus (Figure 1a), whereas molecular analysis by PCR revealed, in the positive samples, amplification products of a size corresponding to the described fragments (Figures $1 \mathrm{~b}$ and $1 \mathrm{c}$ ).

\section{Table 1}

Number and percentage of animals infected with Trypanosoma vivax observed by blood smear analysis (ES) and molecular analysis (PCR) in different counties in the southern mesoregion of the state of Bahia, Brazil

\begin{tabular}{|ccccccccc}
\hline \multirow{2}{*}{ Results* } & \multicolumn{2}{c}{ Ibirataia } & \multicolumn{2}{c}{ Prado } & \multicolumn{2}{c}{ Jucuruçu } & \multicolumn{2}{c}{ Total } \\
\cline { 2 - 10 } & $\begin{array}{c}\text { Number of } \\
\text { animals }\end{array}$ & $\%$ & $\begin{array}{c}\text { Number of } \\
\text { animals }\end{array}$ & $\%$ & $\begin{array}{c}\text { Number of } \\
\text { animals }\end{array}$ & $\%$ & $\begin{array}{c}\text { Number of } \\
\text { animals }\end{array}$ & $\%$ \\
\hline (-) ES / (-) PCR & 84 & 80.0 & 338 & 77.9 & 83 & 98.8 & 505 & 81.1 \\
\hline (-) ES / (+) PCR & 21 & 20.0 & 95 & 21.9 & 0 & 0.0 & 116 & 18.6 \\
\hline (+) ES / (+) PCR & 0 & 0.0 & 1 & 0.2 & 1 & 1.2 & 2 & 0.3 \\
Total & 105 & 100.0 & 434 & 100.0 & 84 & 100.0 & 623 & 100.0
\end{tabular}

*(+) positive; (-) negative. 


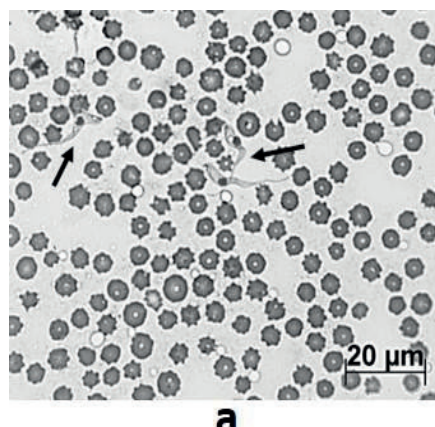

a
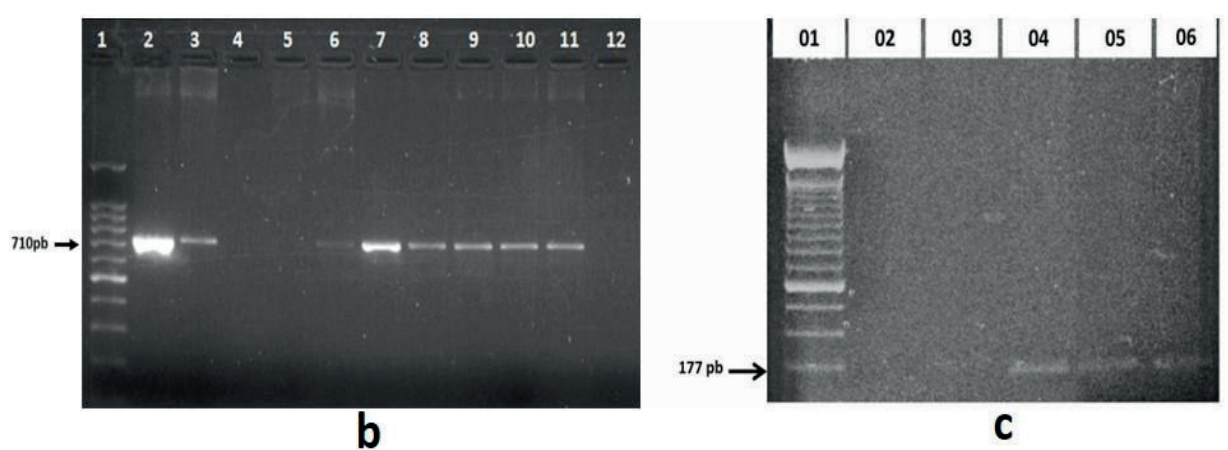

Figure 1. (a) Blood smear showing a trypomastigote form of free T. vivax in blood plasma -arrow (Panoptic staining, 100x objective lens); (b) T. vivax amplification products by PCR using primers specific to the 18SrRNA ribosomal subunit (710 bp). 1: molecular weight marker (100 bp), 2 and 3: positive control, 4: negative control, 5: ultrapure water, 6 to 11: positive sample, 12: negative sample; (c) T. vivax amplification products by PCR using primers specific to cathepsin gene (177 bp). 01: molecular weight marker (100 bp), 02: negative control, 03 to 05: positive samples, 06 : positive control.

Similar percentages of animals tested negative for the presence of T. vivax in the counties of Ibirataia and Prado with values of $80.0 \%$ and $77.9 \%$, respectively, through both the blood smear analysis and molecular analysis by PCR. In the county of Jucuruçu, 83 (98.8\%) out of 84 samples tested negative for the presence of the hemoparasite through both blood smear and PCR analysis. It was observed that $20.0 \%$ of the samples from Ibirataia and $21.9 \%$ from Prado presented negative results through blood smear analysis, but positive by PCR analysis. It was also observed that only one sample from Prado and one from Jucuruçu tested positive through both blood smear and molecular analysis by PCR (Table 1).

In the Northeast region, outbreaks mainlyoccur in the states presentin the semiarid region (Rodrigues et al., 2015). The occurrence of $T$. vivax had been reported in a cow in Piauí through blood smear analysis (Lopes et al., 2018) with a history of animal acquisition in the state of Ceará. Other occurrences have been reported in Maranhão (Pereira et al., 2018) and
Sergipe (Vieira et al., 2017), where 15 blood samples were collected and evaluated using parasitological and molecular methods, and $34 \%(5 / 15)$ were positive in the blood smear analysis, while using PCR 80\% (12/15) samples amplified parasite DNA. This shows the importance of PCR in diagnosis.

The suspicion of a trypanosomiasis outbreak in Pernambuco and Alagoas led to the examination and subsequent diagnosis of $15 \%$ (17/109) positive animals using conventional PCR and 9\% (10/109) using blood smear analysis (Andrade et al., 2019). However, in our study, only $2(0.3 \%)$ of the 623 samples tested positive for T. vivax using the blood smear analysis method (Table 1). These varying percentages can be explained by different factors. According to Amorim et al. (2014), the analysis of blood smears is considered effective in detecting $T$. vivax in animals that present with acute disease but is ineffective in detecting chronic and/or subclinical disease. It should also be noted that asymptomatic animals, or those with subclinical disease, might 
test negative in parasitological exams because in the asymptomatic phases the hemoparasite may be present in the extravascular regions such as the lymph nodes and not in the blood.

Molecular analysis revealed that $18.9 \%$ of the samples tested positive for $T$. vivax (Table 1), including 20.0\% from Ibirataia, 22.1\% from Prado, and $1.2 \%$ from Jucuruçu. In the studies carried out by Vieira et al. (2017), in 15 animals from dairy cattle herds in the state of Sergipe, $80.0 \%$ tested positive for T. vivax by $\mathrm{PCR}$. This variation in the final percentages of T. vivax detection by PCR analysis can also be explained by several factors, such as herds being raised in different geographical regions, age of the animal, genetic variability of the hemoparasite (Cortez et al., 2009), fluctuation of parasitemia, or even aparasitemic intervals (Almeida et al., 2010).

In this study, the results indicated that molecular analysis showed greater reliability for the detection of hemoparasites than blood smear analysis. As shown in Table 1, only $0.3 \%$ of the animals were shown to be infected by the analyses of blood smears, whereas by PCR, this percentage was 63 times greater (18.9\%), suggesting a possible spread of T. vivax in the southern mesoregion of the state.

According to Lopes et al. (2018), the outbreaks of $T$. vivax observed in recent years in Brazil are precisely due to the lack of rapid diagnosis of the hemoparasite, providing it sufficient time to multiply, evade the immune system, and infect new hosts. This is further aggravated by the abundance of mechanical vectors; hence, accurate diagnosis is important at any stage of parasitemia.

A necessary measure to prevent outbreaks would be to control trading and transportation of animals from regions where hemoparasitosis due to T. vivax is diagnosed to regions free from T. vivax by ensuring that transit of cattle between regions only takes place upon proof that the animals are not infected (Pimentel et al., 2012). The possibility of sexual transmission has been recently demonstrated by detecting $T$. vivax in semen, which can also contribute to increased transmission rates of the disease (Bezerra et al., 2018).

This is the first report of the occurrence of T. vivax in the southern mesoregion of Bahia state. We found that PCR analysis was more reliable than blood smear analysis in detecting T. vivax, highlighting the need to adopt more efficient techniques for the diagnosis and control of T. vivax in Bahia as well as to determine its prevalence and spread in the region.

\section{Ethics Committee}

This study was approved by the Ethics Committee for the Use of Animals (CEUA) of the UFBA School of Veterinary Medicine, SalvadorBahia: protocols 28/2016 and 17/2017.

\section{Conflict of Interest Statement} interest.

The authors declare no conflict of

\section{Acknowledgment}

We thank the Conselho Nacional de Desenvolvimento Científico e Tecnológico/ CNPq, Fundação de Amparo à Pesquisa do Estado da Bahia/FAPESB, and Dr. Marta Maria Geraldes Teixeira (Departamento de Parasitologia do Instituto de Ciências Biomédicas da Universidade de São Paulo USP, São Paulo, Brasil). 


\section{References}

Almeida, K. S., Freitas, F. L. C., Tebaldi, J. H., Alessi, A. C., Machado, R. Z., \& Nascimento, A. A. (2010). Alterações clínicas, histopatológicas e enzimáticas em ovinos infectados experimentalmente por Trypanosoma vivax. Ciência Animal Brasileira, 11(3), 669-676. doi: 10.5216/ cab.v11i3.5971

Amorim, L. S., Wenceslau, A. A., Carvalho, F. S., Carneiro, F. S., Carneiro, P. L. S., \& Albuquerque, G. R. (2014). Bovine babesiosis and anaplasmosis complex: diagnosis and evaluation of the risk factors from Bahia, Brazil. Revista Brasileira de Parasitologia Veterinária, 23(3), 328-336. doi: 10.1590/s1984-29 612014064

Andrade, A. Q., Neto, Mendonça, C. L., Souto, R. J. C., Sampaio, P. H., Fidelis, O. L., Jr., André, M. R., \& Afonso, J. A. B. (2019). Diagnostic, clinical and epidemiological aspects of dairy cows naturally infected by Trypanosoma vivax in the states of Pernambuco and Alagoas, Brazil. Brazilian Journal of Veterinary Medicine, 41(1), e094319. doi: 10.29374/2527-2179.bjvm 094319

Araújo, F. R., Ramos, C. D. N., Luiz, H. L., Péres, I. H. F. S., Oliveira, R. H. M. de, Souza, I. F. de, \& Russi, L. D. S. (2009). Avaliação de um protocolo de extração de DNA genômico a partir de sangue total. (Comunicado Técnico, INFOTECA-E, 120). Campo Grande, MS: EMBRAPA Gado de Corte. Recuperado de https://www. infoteca.cnptia.embrapa.br/bitstream/ doc/853364/1/COT120.pdf

Bastos, T. S. A., Faria, A. M., Madrid, D. M. D. C., Bessa, L. C. D., Linhares, G. F. C.,
Fidelis, O. L., Jr., \& Machado, R. Z. (2017) First outbreak and subsequent cases of Trypanosoma vivax in the state of Goiás, Brazil, Revista Brasileira de Parasitologia Veterinária, 26(3), 366-371. doi: 10.1590/ s1984-29612017019

Bezerra, N. M., Moura, G. H. F., Araújo, H. N. de, Bezerra, F. S. B., Paiva, K. A. R. de, Costa, K. M. D. F. M., \& Batista, J. S. (2018). Detection of Trypanosoma vivax DNA in semen from experimentally infected goats. Veterinary Research Communications, 42(2), 131135. doi: 10.1007/s11259-018-9715-3

Cortez, A. P., Rodrigues, A. C., Garcia, H. A., Neves, L., Batista, J. S., Bengaly, Z., \& Teixeira, M. M. (2009). Cathepsin L-like genes of Trypanosoma vivax from Africa and South America - characterization, relationships, and diagnostic implications. Molecular and Cellular Probes, 23(1), 4451. doi: 10.1016/j.mcp.2008.11.003

Grisi, L., Leite, C., Martins, J. R. D. S., Barros, A. T. M. D., Andreotti, R., Cançado, P. H. D., \& Villela, H. S. (2014). Reassessment of the potential economic impact of cattle parasites in Brazil. Revista Brasileira de Parasitologia Veterinária, 23(2), 150-156. doi: 10.1590/s1984-29612014042

Lopes, S. T. P., Prado, B. D. S., Martins, G. H. C., Beserra, H. E. A., Sousa, M. A. C. D., Fo., Evangelista, L. S. D. M., \& Souza, J. A. T. D. (2018). Trypanosoma vivax em bovino leiteiro. Acta Scientiae Veterinariae, 46(1), 287. doi: 10.22456/1679-9216.86772

Madruga, C. R. (2004) Diagnóstico e epidemiologia do Trypanosoma (Duttonella) vivax no Brasil. Revista Brasileira de Parasitologia Veterinária, 13, (Suppl 1), 46-47. 
Madruga, C. R., Araújo, F. R. de, Lima, S. C., Jr., \& Pádua, E. S. P. (2006). Comparação de métodos de extração do DNA e avaliação de reações da polimerase em cadeia (PCR) para o diagnóstico de Trypanosoma (Dutonella) vivax. (Circular Técnica, INFOTECA-E, 34, 1-8). Campo Grande, MS: EMBRAPA Gado de Corte. Recuperado de http://www.infoteca.cnptia.embrapa.br/ infoteca/handle/doc/ 326896

Pereira, H. D., Simões, S. V., Souza, F. A., Silveira, J. A., Ribeiro, M. F., Cadioli, F. A., \& Sampaio, P. H. (2018). Aspectos clínicos, epidemiológicos e diagnóstico da infecção por Trypanosoma vivax em rebanho bovino no estado do Maranhão. Pesquisa Veterinária Brasileira, 38(5), 896901. doi: 10.1590/1678-5150-pvb-5303

Pimentel, D. S., Ramos, C. A. N., Ramos, R. A. N., Araújo, F. R., Borba, M. L., Faustino, M. A. G., \& Alves, L. C. (2012). First report and molecular characterization of Trypanosoma vivax in cattle from state of Pernambuco, Brazil. Veterinary Parasitology, 185(2-4), 286-289. doi: 10. 1016/j.vetpar.2011.10.019
Rodrigues, C. M., Batista, J. S., Lima, J. M., Freitas, F. J. C., Barros, I. O., Garcia, H. A., \& Teixeira, M. M. G. (2015). Field and experimental symptomless infections support wandering donkeys as healthy carriers of Trypanosoma vivax in the Brazilian Semiarid, a region of outbreaks of high mortality in cattle and sheep. Parasites Vectors, 8(1), 1-11. doi: 10.1186/ s13071-015-1169-7

Vieira, O. L. E., Macedo, L. O. D., Santos, M. A. B., Silva, J.A.B. A., Mendonça, C. L. D., Faustino, M. A. D. G., \& Carvalho, G. A. D. (2017). Detection and molecular characterization of Trypanosoma (Duttonella) vivax in dairy cattle in the state of Sergipe, northeastern Brazil. Revista Brasileira de Parasitologia Veterinária, 26(4), 516-520. doi: 10.1590/ s1984-29612017048 
